\title{
Living Experiments: Beauvoir, Freedom, and Science
}

\author{
AnNa MudDE
}

Beauvoirean ambiguity is evinced in action as the movement of human freedom that is always constrained, in ways that we cannot always anticipate or control; our actions exceed us, and in producing things in the world for others, they are always also surpassed. For this reason, in The Ethics of Ambiguity, Simone de Beauvoir argues that Western thinking about science exemplifies a moral and ontological mistake about human freedom. Scientists who understand themselves to posit final truth will be frustrated by a world which challenges finality, dooming themselves to failure. She writes:

Science condemns itself to failure when, yielding to the infatuation of the serious, it aspires to attain being, to contain it, and to possess it; but it finds its truth if it considers itself as a free engagement of thought in the given, aiming, at each discovery, not at fusion with the thing, but at the possibility of new discoveries; what the mind then projects is the concrete accomplishment of its freedom (Beauvoir, Ethics 79).

Despite Beauvoir's rejection of the metaphysical and epistemological assumptions about our access to truth made by (some) scientists and about science, we are misled if we take her to be always already set against the scientific. As a practice, or set of practices, scientific work or activity seems to confirm what Beauvoir sees as constant in human life: scientific engagements reveal both the situatedness and the ambiguity of the human beings who try to know. Through human action, situated freedom makes worldly facticity into something meaningful. To will to know is to will freedom, and Beauvoir often appeals to examples of science to demonstrate this feature of consciousness.

Earlier in the Ethics, Beauvoir argues that to live authentically and responsibly requires human beings to "assume" their inherent ambiguity (9). In this paper, I imagine a form of morally and metaphysically responsible subjectivity that might arise from taking Beauvoir's insights about science seriously. I argue that we might fruitfully read Beauvoir's call to ambiguity, in the Ethics, as a call to live experimentally. That is, I 
read the call to ambiguity as a call to take up a form of subjectivity, a stance toward the world, which assumes that to engage oneself, to act or try to know, is necessarily to experiment, to suggest meaning to others and in the world. I therefore propose a lived ethos of experimentation, where experimentation is read as an "art of living," a way of being in the world and with others, having let go of the fiction that one is, as Beauvoir puts it, a "sovereign" subject. My approach is to highlight her concern with the inherent ethicality of knowing by drawing upon (and thus cataloguing) a number of instances of Beauvoir's use of scientific examples, particularly in her earlier works on action and ambiguity (especially "Pyrrhus and Cineas" and The Ethics of Ambiguity).

To begin, however, I look to an unlikely intellectual source to bring forward some of the important themes I see emerging from Beauvoir's thought. I locate a point of contact with more recent (feminist) thinking about science by looking to Donna Haraway, who is also interested in situated subjectivity. ${ }^{2}$ Specifically, I take up Haraway's use of diffraction as a trope to read Beauvoir's thinking about scientific ambiguity.

\section{New Situations}

In her 1944 essay on freedom and action, "Pyrrhus and Cineas," Beauvoir writes, in the section called "Humanity:" "It is true that all men agree about science, since a thought is scientific only when it is such that all men can agree upon it." (110) Throughout this section, Beauvoir treats science as an example of human practice-in this case, practices pertaining to or resulting from thought and experience, with both situated and universalizable consequences. She immediately continues: "But in working for science, is it really for humanity that one works? Each one of its inventions defines a new situation for men." ("Pyrrhus and Cineas" 110) One works for the humanity one produces; knowledge-builders try to know that which they produce by trying to know. Scientific thought may

\footnotetext{
${ }^{1}$ Beauvoir introduces this term in her novel, Les mandarins. See Karen Vintges's superb analysis of Beauvoir's "art of living" in her Philosophy as Passion: The Thinking of Simone de Beauvoir, which has interesting points of contact with my thinking, here. My thanks go to an exceptionally generous anonymous reviewer for drawing my attention to this resonance.

2 See Haraway, Simians 183-201. While there are reasons to question any claim to historical or methodological connections between Beauvoir's work and Haraway's, Edward Fullbrook and Kate Fullbrook have noted that Beauvoir's philosophical method, which rejects any presumption of an Archemidean "view from nowhere," prefigures much post-modernist work on subjectivity, like Haraway's. My claim is that Beauvoir's reliance on scientific examples and analogies reveals an important ambiguity between being a radically individual and differentiated subject and one who is dealing with a world that is shared, in complex ways, with others. See Fullbrook and Fullbrook 39.
} 
be a matter of "humanity's" knowledge, but the scientific thought or invention she has in mind is, more than this, a producer of "new situations" for human lives.

In "Pyrrhus and Cineas," Beauvoir uses science to exemplify particular features of human consciousness, which not only gives the world meaning, but which also, necessarily, finds meaning in the worldfor itself and through the meanings given to it by others. Donna Haraway's thinking about subjectivity and the differences subjects make in the world by trying to know not only draws attention to important features of Beauvoir's work, it emphasizes the worldly impact of knowing for which knowers must be responsible. ${ }^{3}$ Pausing, briefly, to consider Haraway's use of "diffraction," I will then move on to consider the ways Beauvoir employs science as an illustration of ambiguous situation and its production. I consider how "humanity's" knowledge necessarily begets the "new" situations of "humanity," and of why this might constitute an important - and existential — anchor for thinking about knowing-being in the world.

Haraway has intriguingly described herself as "a child of Boyle's Royal Society," attached to "the figure of the modest witness" (Haraway, Modest_Witness 267), the objective, scientific subject-knower of universal worldly "facts." She writes,

... the modest witness is the legitimate and authorized ventriloquist for the object world, adding nothing from his mere opinion, from his biasing embodiment. And so he is endowed with the remarkable power to establish facts. He bears witness: he is objective, he guarantees the clarity and purity of objects. His [modest] subjectivity is his objectivity. (Haraway, Modest_Witness 24)

Like many theorists of science, Haraway has argued that this traditional model of scientific knowing and its objective subject-knower did not acquire their status and significance directly. Instead, for Haraway, objective "modest witnesses" are subjectivities historically tied to Robert Boyle's (1627-1691) seventeenth laboratory at the Royal Society of London. With civil wars over disputed political and religious authority raging around him, Boyle developed an apparatus that would evacuate air from a transparent glass tube, to investigate the "nature" of air. Boyle's approach established that matters of fact can be based purely on human sense data, available (in principle) to anyone who witnesses an

\footnotetext{
${ }^{3}$ My goal in situating Haraway's diffractive knowers and Beauvoir's view of ambiguous being in the world is not to ally Haraway and Beauvoir or to think them too closely together; instead, I am using Harawayan diffraction to open spaces for thinking about the ways in which the Beauvoirean use of science nuances her proposed ethical stance, as an orientation to being human, emerging from and giving us access to the ambiguous.
} 
experiment - conceived as nature in action, made visible by strong and transparent glass. What was established in the lab could be universally true, since, the argument goes, anyone with eyes would agree with what the others witnessed there: ${ }^{4}$ the measured rule used to chart the movement of mercury in a glass tube does not lie, a bird placed in the chamber cannot pretend to suffocate, ${ }^{5}$ and neither is influenced by the social or political values of their knowers-Boyle's witnesses were "modest witnesses," like him. ${ }^{6}$ Boyle's work enacted, using Beauvoir's term, "new situations," new possibilities for "humanity," for subjectivity, and for truth: knowers could see and thus know the world "as it is."

Through her consideration of Boyle's contribution to humanity's situation(s), the differences he made in the world, in Modest_Witness, Haraway argues that if knowers are to be responsible for the effects of their knowing, then their practices of knowing/seeing must involve relentless making-visible the processes of crafting subject positions (197).

Worried about practices of making-visible that rely on the trope of reflection, the reproducer of sameness, Haraway emphasizes thinking about the differences knowers make in the world and for others (Modest_Witness 16). Diffraction, the creation of patterns of physical interference, is for her a preferable trope (over reflection) for the effects of knowing. Diffraction is "a mapping of interference, not of replication, reflection, or reproduction. A diffraction pattern does not map where differences appear, but rather maps where the effects of difference appear." (Haraway, "Promises" 300). To try to know, in Haraway's work, is to produce difference(s); located subjects-"situated knowers" (Haraway Simians 183-201) — and their practices are thus made-visible in part by the patterns of difference they produce in the world. Being alert to the production of difference is possible because knowers are situated amongst (different) others and in the world.

\footnotetext{
${ }^{4}$ Much of Boyle's work is unpublished; the unpublished manuscripts are available (though not entirely legible) online at The Boyle Project.

${ }^{5}$ Elizabeth Potter describes Boyle's report of women disrupting experiments by objecting to the deprivation of oxygen to a suffocating bird that was clearly suffering. Though the Royal Society admitted women to view its experiments in the early days of its practice, they were excluded from membership in the Royal Society until 1945. See Potter 16-21, as well as Shapin.

${ }^{6}$ In the seventeenth century, those admitted as members of the Royal Society of London were "gentlemen," a category that excluded persons "covered" by their fathers, husbands, or brothers, as women were, and persons financially dependent on others for their employment and thus survival. As Steven Shapin notes, gentlemen, by comparison, were conceived in the public imagination to owe nothing but the truth to anyone- they had, by definition, no relations that would cause them to report socially interested observations. See Shapin.
} 
To make the best use of this point, it helps to think of the physical phenomenon upon which Haraway draws. Diffraction is a feature of wave behaviour; it occurs when waves encounter an obstruction, or when two (or more) wave patterns overlap one another. When one wave pattern crosses over or interferes with the other, the resulting phenomenon is an instance of diffraction. Both the production of waves and their diffractive reactions reveal a physical world in which each worldly happening makes a difference, often shifting the course of, or overlapping with, an established pattern - as the wave pattern of one stone is changed by and changes the wave pattern of the other stone. In laboratory science, the use of instrumentation provides other instances of physical interaction or interference - to experiment in the laboratory is largely to make a difference in order to test how worldly things will react, what phenomena the interference will produce. ${ }^{7}$ Knowing the world through science, on this view, is not to know "nature itself," but to know worldly phenomena insofar as human beings can interact with and create them. As a result, there is no pure laboratory witnessing; empirical experiences are worldly (or physical) responses to worldly phenomena, insofar as the world responds to human engagements/interference. The knowing practices that come from and precipitate such interference(s), are, Haraway suggests, diffractive, too. As she describes it, "Diffraction patterns record the history of interaction, interference, reinforcement, differences," and are not about "displac[ing] the same elsewhere, in more or less distorted forms ... Diffraction is a ... technology for making consequential meanings" (Modest_Witness 273). Our actions express diffractively, outward, in ways that interact and interfere with, reinforce or make different, the world.

Like Haraway, Beauvoir notices that it is through our concrete worldly engagements - which include the attempt to know the world and the positing of ideas about it - that we at once make meaningful worldly differences and gain access to the meaning, or situation, of ourselves. Indeed, for Beauvoir, the very attempt to stand back from the world and to know it objectively, "as it is," reveals one's own connections with it. She writes in a 1964 round-table contribution:" "Man cannot escape his own presence or that of the singular world that his presence reveals around him. His very effort to tear himself away from the earth only carves out his place there. Spinozism defines Spinoza, and Hegelianism defines Hegel." (Beauvoir, "What Can Literature Do?," 101-102)

The challenge, then, is to recognize that one's apparent freedom is better understood as a unique set of connections with the world, connections which constrain how freedom will be manifested concretely. To try to know reveals those connections-one's situation-through

\footnotetext{
${ }^{7}$ See also Karen Barad's work (2007) on diffraction, in dialogue with Haraway.

${ }^{8}$ See Hengehold's introduction to "What Can Literature Do?" 192.
} 
(using Haraway's term) the diffractive effects one produces in the world. Noting those effects reveals the inherent ambiguity of those engagements; the attempt to separate oneself from the world in order to say what it (or any of its parts) means, reveals one's place in it.

Drawing on this insight, we might notice that in science, one engages oneself more self-consciously or explicitly than in many of the more mundane engagements of human life, and with a particular aim: scientific work and thought are explicitly attempts to know the world. In thinking about the approach to science I am suggesting that Beauvoir offers, I find that what emerges is an important feature of lived experience, which Beauvoir takes up in her work on (and in) literature and philosophy, both of which are structured by an underlying, "diffractive" metaphysical attitude. While Beauvoir opposes metaphysics as an enterprise of systembuilding or serious assertion of fixed and final truth, ${ }^{9}$ she also opposes the idea that lived experience of one's situation is not always already metaphysically salient, for oneself, for the world, and for others. She writes,

Metaphysics is, first of all, not a system; one does not "do" metaphysics as one "does" mathematics or physics. In reality, "to do' metaphysics is 'to be' metaphysical; it is to realize oneself in the metaphysical attitude, which consists in positing oneself in one's totality before the totality of the world. ("Literature and Metaphysics," 273)

To take up the metaphysical attitude, her point seems to be, is not to enter into and use a particular system of making sense-as we enter into systems of mathematics or physics; it is to recognize that one is (as a precondition for entering into any practice, even systematic ones like mathematics or physics) always already metaphysically engaged. It is to know that one necessarily exercises the capacity for positing/disclosing being, not at some objective distance from the world, but by making the world (for others). One is situated, diffractively, we might say, in the world. And in scientific engagements, this feature of our lives is explicitly present and pressing. ${ }^{10}$

Actions, as is clear in scientific practice, create change. To do science is to produce things, to form things, in the world and for others. It is not to leave the world untouched. Indeed, science, Beauvoir claims, helps to produce the possibilities and conditions which human beings live. This is, perhaps, an unsurprising claim to make: science is often taken to be a producer of new spaces of thought, of technologies, of knowledge.

\footnotetext{
${ }^{9}$ Sara Heinämaa's discussion of Beauvoir's rejection of theoretical system-building is especially helpful (177). Also see Holveck 16.

${ }^{10}$ I would like to thank two anonymous reviewers for pushing me to articluate this point.
} 
But Beauvoir does not stop there. She also suggests that the outcomes of those new spaces, technologies, and knowledge are not ones we can always anticipate. What I do, make, and mean in the world is not wholly up to me.

\section{Science and Human Ambiguity}

In Beauvoir's early work, her articulations of situation are closely tied to actions - one's own and those of others. This is a relationship she identifies as paradoxically problematic for the conception of freedom to which she is committed. In "Pyrrhus and Cineas" Beauvoir considers classical and quantum mechanics as potential analogies for articulating the problem of human freedom, particularly when considered through human actions. She writes:

So an action thrown into the world is not propagated infinitely like the wave in classical physics. Rather, the image proposed by the new wave mechanics would appear appropriate here: an experiment can define a wave in terms of probability and give an equation for its propagation, but it does not allow us to predict a later experiment that will throw new givens into the world from which the wave must be reconstructed anew. The action does not stop the instant that we accomplish it. It escapes us toward the future, where it is immediately grasped by a foreign consciousness ... My action is for the other only what he himself makes of it. How then would I know in advance what I do? And if I don't know, how can I intend to act for humanity? ("Pyrrhus and Cineas" 109)

The effects of our actions, like waves, do not "stop the instant we accomplish [them]," but instead "throw new givens in to the world" from which (others') future actions will reconstruct the world anew. While one is, perhaps, free to act, the outcomes of one's actions escape one's control, moving out diffractively towards other beings, like waves, which we do not have the freedom to control.

In her later work on ambiguity, and indeed in her novels and in The Second Sex, the ambiguous features of human action become common, evolving themes. In The Ethics of Ambiguity, Beauvoir argues that ethical thinking appropriate to human life-consciousness and experiencerecognizes ambiguity as the context in which human beings must create values and meaning. There, Beauvoir's appeal to science works as a kind of analogy for ambiguous ways of being human: inseparable from action, at once a movement of freedom, a universal, and grounded in the facticity of human life. 
Science, like other human action, is made meaningful by and in human life, and yet it is not, nor does it produce, a "social construction." To do science is to make meaning, and create possibility, in the world for others. Beauvoir makes productive use of the tension that exists between the idea of science as systematic pursuer of universal truth and the idea of science she prefers, which is oriented toward a more phenomenological analysis of what it is to engage in practices of trying to know the world. ${ }^{11}$ As she suggests in "Pyrrhus and Cineas," science appears at once to try to say what is and to necessarily change - to make a difference for-what is, for human beings and in the world, in a moment of surpassing. Beauvoir's understanding of science is thus intimately entwined with her thinking about freedom. As I quoted from the Ethics at the outset of this paper, Beauvoir writes that science "condemns itself to failure when ... it aspires to attain being, to contain it, and to possess it" (Ethics 79). Yet science need not fail in this way: science allows knowers to "accomplish" their freedom when it "considers itself as a free engagement of thought in the given, aiming, at each discovery, not at fusion with the thing, but at the possibility of new discoveries" (79).

Like science, philosophy, art, and technology all condemn themselves to failure to the extent that they imagine they can find final answers, can solve the problems - that is, resolve the tensions or ambiguities - of being human, including the problem of facing a world that is not meaningful on its own. Science which does not "know itself" to be a mechanism through which human beings can establish values in the world, for others to take up and change, thus does not understand even itself, let alone the world (79). Freedom is not that which decides unilaterally, what the world will mean. On the other hand, she argues, human endeavours fulfill human being when knowers admit that their aims are part of an "indefinite disclosure" of possibilities, that their answers or solutions create the conditions for the further possibilities, answers, and solutions of others. In The Ethics of Ambiguity, scientific practice, where attempts to disclose meaning are explicit and often positive, reveals, for Beauvoir, the extent to which the exercise of human freedom tends toward the failure to disclose fixed truth or fact $(10,79)$, a failure she thinks we are required to assume as part of any attempt at the responsible use of our freedom, our will to know.

But why ought we to assume it? Beauvoir argues that the exercise of freedom implies an assertion or imposition of meaning (78-81). To do science - to do anything at all - is to begin with what one encounters in

${ }^{11}$ Abigail Klassen elaborates how Beauvoir's "method of interrogating the being of beings and reality" (835) is compatible with many accepted pictures of science. She argues that Beauvoir holds a positive skeptical view of science, akin to that of Poincaré, Husserl, Duhem, and Bacon. See Klassen 835-851. 
the world (oneself as posited "before the totality of the world"), and to posit being, willing one's freedom to make and find meaning, into existence. It is to express a hypothesis, a claim based on some prior experience, through action. Such claims are thus tied to the particular facticities of the situated actor, and are at once "transitory" (80) and in the form of axiomatic universals ( $\mathrm{x}$ is such that I can do $\mathrm{y}$ with it). To assume ambiguity is in part to know that one necessarily, in every speech or action, posits meaning in the form of an axiomatic (if transitory) assertion, without at the same time affirming some special or incorrigible knowledge of a human-independent way or content of being, or the freedom to express what the world is (or is like).

Indeed, as the history of science shows, many axiomatically expressed pieces of scientific knowledge have been precisely "transitory." And, as scientific practice so continues to show, I must often comport myself to the world, to the meanings inscribed on it by others, and to the facticities of the world that show up in and through my attempts to establish meanings the world will not "take." Human beings are constrained by experience, and by the world. It is in refusing this structure in experience that we fail. It is, more specifically, the refusal to assume the correction of one's assertions, by the world and by worldly others - the refusal to assume that one is, necessarily, trying things out, experimenting - that one fails.

To experiment is, in the sense I am developing here, to offer to others or the world a situated positing of oneself before the world and others (see Beauvoir, "Literature and Metaphysics" 273). It is to will freedom by offering - as one might offer an hypothesis - one's situated way(s) of making sense, of making the world meaningful to others, but also to the world. It is to recognize that by offering, one is always already positing, claiming what is, expressing what one takes the world to be. Yet, taken up as practice, I can orient myself toward making such an offering tentatively, if passionately, as a way of "trying out" my ways of making sense, such that they might be meaningful or helpful to others. ${ }^{12}$ Responsive to worldly facticity, "facts," in this case, are best understood not as fixed certainties that we have discovered - the view of scientific practice that Beauvoir rejects-but as offerings taken up by those who are situated such that they can "agree" about what they see in the world by finding they are able to take up particular meanings in their thoughts and actions (Beauvoir, Second Sex 46). "Facts" are thus both situated as well as revisable, and disciplined by (appeal to) the world.

\footnotetext{
12 Vingtes discusses Beauvoir's idea that the role of philosophy and literature is to be "concrete support" for others in the living of their lives (92-94).
} 
In reading Beauvoir's reflections on writing fiction and philosophy with this approach in mind, I find that something like experiment, the "trying out" of connections, meanings, or values, is, in much of Beauvoir's work, central to human consciousness. In the remainder of this paper, I will consider how an experimental approach expands out into her work in general, including her work on fiction and on the meanings of sex distinctions in The Second Sex. In that light, I see space for a more nuanced, diffractively engaged philosophy and philosophical subject(ivity) to emerge. Such an ethos would, as I am envisioning it, rely heavily on the Beauvoirean importance of recognizing knowers as situated ambiguities, engaged in practices of finding and creating meaning, necessarily tied to a real and resilient world.

\section{Literary Experiments}

Edward Fullbrook argues that one of Beauvoir's most distinctive theses is that consciousness is not only a desire to be but also a desire to reveal being (Fullbrook 33-40). ${ }^{13}$ In her novels, she accesses this ambiguity by describing her characters' perceptions, by "taking delight in the pure witnessing of the world and oneself" (39), and allowing her descriptions of the world's particular concreteness to arise "in such a way that its meanings emerge," that is, in such a way that both worldly phenomena and the philosopher's "intuition of significance will become clear" (Warnock 136). It is "plain," Mary Warnock writes, "how close such a method is to the methods of the novelist, the short-story writer" (136). But it is also "plain" how close such a method is to methods of experimentation.

In "Literature and Metaphysics," Beauvoir describes successful fiction, insisting that the plot is not a pure mechanical unfolding, that "a novel is not a manufactured object" (Beauvoir, "Literature and Metaphysics" 271). While it would be "absurd" to claim that a novel's protagonist is free, the freedom of the author's characters "is the freedom that the novelist himself has with regard to his own projects; and the opacity of the events he relates shows the resistance that he encounters during the creative act itself" (271-272). To explain what she means, Beauvoir herself draws an analogy between writing fiction and the process(es) of scientific experimentation- "novelistic experiment" (272). She writes:

Just as a scientific truth finds its worth in the totality of the experiments that found it and are summed up by it, so the work of

\footnotetext{
${ }^{13}$ There is an ample and growing body of work on Beauvoir's fiction as philosophically salient. See, for example, Merleau-Ponty 1964, Holveck 2002, Mary Sirridge 2003, and Sara Heinämaa 2006.
} 
art comprises the singular experiment of which it is the fruit. The scientific experiment is the confrontation of the fact, that is, of the hypothesis considered as verified, with the new idea. In an analogous manner, the author must constantly confront his sketches with their realization, which is outlined by them and immediately reacts upon them... at the end of his creation, he will consider the work he has accomplished with astonishment (272).

The quality of worldly possibility found in novels (compared with, for example, the reporting of "fact") does not signify that an author can write the world in any way he or she likes; though what one reads in a novel is unquestionably tied to a particular author, the novel will fail if the author imposes him- or herself too much on the world, if he or she does not recognize that, as Beauvoir puts it in "A Review of The Phenomenology of Perception by Maurice Merleau-Ponty," "[t]hings speak to us" (162), we do not only speak of them. Novelistic experimentation must, in a sense, "fit" the world, confronting "the fact" with "the new idea" (Beauvoir, "Literature and Metaphysics" 272). ${ }^{14}$ It is experimental because it necessarily involves a trying-out or, indeed, "experimentation"-and experimentation for Beauvoir, as I am suggesting, relies on a conditioned use of freedom where the outcome cannot be assumed; the author is often "astonished." It is, moreover, in the reception of literary, as well as scientific, technological, industrial, cultural, work by others that authorial impositions of meaning - especially ill-fitting proposals of "fact" —are most clearly revealed.

In the section of The Second Sex entitled "Biological Data," for instance, Beauvoir exemplifies this relation between imposing meaning and finding "facts" by appealing to the manner in which philosophers have dealt with, found/"found" meaning in, the fact of sexually differentiated bodies. ${ }^{15}$ Many philosophers" "experiments" have failed. Indeed, Beauvoir's critique of Hegel's analysis of sex is particularly illustrative

\footnotetext{
${ }^{14}$ Beauvoir's analysis of Merleau-Ponty's Phenomenology echoes work from her student days. Like many students of her time and place, she read Claude Bernard's 1865 study of scientific practice in his Introduction to the Study of Experimental Medicine, sections of which are the subject of one of Beauvoir's student papers (Beauvoir "Analysis"). This is how Beauvoir explains the process of scientific knowledge according to Bernard: "First, a fact is noted. Second, an idea is born in the mind concerning the fact. Third, with this new idea in view, the scientist reasons, sets up an experiment, and executes it. Fourth, this experiment reveals a new fact and so forth... the experimenter [can only prove] with facts the preconceived idea suggested to him by an observation." ("Analysis" 27-28) Knowers spontaneously try to find out and understand how the world "works," and yet the world does not let them away with just any hypothesis or intuition they can suggest.

${ }^{15}$ Beauvoir considers accounts of sex difference in Plato, Aristotle, Aquinas, and Hegel in the Introduction to The Second Sex.
} 
not only of her view of the supposed "biological" meaning of sexual difference, but of a failed experiment.

For Hegel, the meanings of biological sexual difference do not express or arise from the heterosexual meanings embodied human beings have been made and allowed to live. Instead, for Hegel, sexual difference expresses what are actual, unchanging differences, only overcome through (hetero-)sexual "copulation" (Beauvoir, Second Sex 23), through which men and women "establish" and "find the sense" of themselves as subjects, distinct individuals inseparable from one another. ${ }^{16}$ Beauvoir is amenable to the idea that we discover through our actions the meaning and particularity of our situations vis-à-vis the situations of others and in relation to the general situatedness of humanity as a whole. But, for her, the very concepts of biology, often used to compare woman's being with man's, are part of a situated, established system of values and "facts," which is itself only intelligible against a broader background of existence, a totality, by reference to "existentialist, economic, and moral reference points" (46).

Beauvoir's claim, then, is not that the human species and its situations are "antinatural" or cultural alone. Such a view is unjustified, she writes, to the extent that human beings deal with facticities regarding, for example, men's and women's bodies, features of the world that "cannot be denied." But those facticities "do not carry their meaning in themselves:" "nature has reality for [human beings] insofar as it is taken on by [their] action: [their] own nature is no exception" (Second Sex 46). Hegel is right, Beauvoir argues, that sex difference involves differences of "fact" - of physical particularities that carry socially specific meanings, upon which, perhaps, some people "agree" ("Pyrrhus and Cineas" 110). But her telling critique, in line with her more general thinking about science, is that Hegel takes (unnecessarily, she thinks, given his general approach) those differences to neither express nor identify an instance of meaning-giving, but to signify manifestly dichotomous existence. He misunderstands what he is doing-he takes himself to be simply describing the world (discovering facts) instead of experimenting with it or dealing with the experimentation of previous others (working with or suggesting possible "facts"). As such, read as experiment and assessed through a lens privileging ambiguity, Hegel's analysis of sex difference is unconvincing: "one feels in it too distinctly," Beauvoir writes, "the preconceived idea of locating the three moments of the syllogism in any operation is too obvious here" (Beauvoir, Second Sex 23, my emphasis). The problem with Hegel's preconception for Beauvoir (and perhaps for

\footnotetext{
${ }^{16}$ See Hegel's Philosophy of Nature 411, $\$ 368-369$ (The Sex-Relation). This passage is translated from Nicolin and Pöggeler's edition (1959) and from the Zusätze in Michelet's text (1847).
} 
many of us), as I am reading it here, is not that he has a preconceptionwhich is a requirement of expressing freedom concretely in action-but that he insists on it, and one "feels" (rightly, I think) he is not open to correction.

In philosophical texts, as in science, knowers make worldly facticity meaningful. But to impose an agenda too insistently renders the "story" one is telling unconvincing, the "experiment" will be unsuccessful if one does not let the world speak to us - that is, if one does not take oneself to be experimenting to begin with. The world does not "take" just any meaning human beings can give to it. And yet, Hegel's ability to find intelligibility in what Beauvoir argues is at best a historically and culturally specific way of dealing with (bodily) "facts" also indicates that the extent to which the world can "take" meaning is inextricable from the meanings given to it by our past and present others - a point upon which, Beauvoir knows, Hegel himself insists. ${ }^{17}$ Others have made the world meaningful in ways that condition the meanings I can now posit, the worldly capacity to accept or deny them, and the likelihood that others can "agree" with me. ${ }^{18}$ Thus, what one's actions, self, and words mean, the significance of one's experiential and intellectual relations with the world, is never up to oneself alone; one's own actions, self, and words, are diffractively engaged.

In Beauvoir's criticisms of Hegel, both in the Ethics and in The Second Sex, I read a special sort of frustration. Hegel's theory of sex difference fails not primarily because he is wrong, but because he pronounces an axiomatic ontological truth without assuming that the world will exceed his capacity to articulate it, and without assuming that

${ }^{17}$ In thinking about the relationship between existentialist novels and metaphysics, Iris Murdoch underscores their mutual grounding in the Hegelian idea of the subject: "In the Hegelian world reason has a history, that is the subject has a history, and is in a state of war with his environment and with other subjects. With Hegel the real subject enters philosophy. It is true that Hegel holds that 'all is ultimately reconciled in the Absolute'. But what interests Hegel, at any rate in the Phenomenology, is not the goal but the way... at any time before the end of history, there are contradictions that remain unresolved" (103).

${ }^{18}$ While it is beyond the scope of my discussion here, the likelihood of having one's meanings "take" or be agreed upon is deeply connected to one's situatedness. Specifically, living oppression is, as Beauvoir describes in the Ethics, characterized by the inability to engage freedom to find one's own meaning in the world, and she notes that this inability is never the not of the world itself, but of structures of power (e.g., Ethics 80). Part of living oppression is, perhaps and in part, the disqualification from having others who can (will) "agree" with you. Taking up an experimental stance does not put oneself in the position of the oppressed, but it does or can take seriously the more general human situation of being unable to live freedom as "this free unfurling of itself" (80), which I take to be a central to position in this paper. 
in articulating it he might, in part, make it meaningful in some ways and not others - that is, in the ways only Hegel could do. Hegel forgets that what he both finds and reveals is, in part, himself as situated, within and before the world.

To live experimentally, I suggest, involves taking seriously the diffractive feature of human activity. Living experimentally, then, necessarily implies an assumption of responsibility, which is not a matter of choosing to take up something one did not have before, but is instead a matter of taking seriously what one is always already responsible for. Indeed, I am responsible, on this approach, even when I am not making self-conscious offerings to others and the world. My very desires and actions express values and ways of making sense (see Mudde). The aim of taking up an experimental ethos is, borrowing Sonia Kruks' words, "to make explicit the values present in our actions while also recognizing our responsibility for the power-effects they produce" (Kruks 70). To assume experimentation is also in part, then, to make some space to do and to see what one has done; it is to inhabit the world such that one might take seriously the results of one's actions as tied to oneself; it is to allow oneself to know oneself through one's diffractive effects; it is to know that those effects are often other than what one might have expected; it is to allow oneself to be "astonished," and to be responsible for that which is astonishing. To experiment, self-consciously or not, is thus to act with the anticipation of this structure. This fits Beauvoir's view of being human, of freedom and subjectivity that, as Nancy Bauer aptly reads it, involves "risking ourselves" (and others) by acting in the knowledge of our "responsibility for co-authoring the world" (Bauer 236). For Beauvoir, to do otherwise constitutes an act of bad faith; responsibility requires an assumption of ambiguity.

While I have been emphasizing the role that an experimental ethos might play in theory-making, fiction, and science, I hope that-in considering Beauvoir's reading of Hegel, for instance-it is clear the extent to which such experimentation is inextricable from real, lived, human life. ${ }^{19}$ To conclude and to reinforce that approach, I draw Bauer's point about co-authorship back toward the suggestion of an experimental ethos and the Harawayan reading of diffraction with which I began.

\section{Experiment and the Metaphysical Stance}

Despite Hegel's inability to see around the historical, material, and "factual" intelligibility of sexual differentiation, one of Beauvoir's most important insights in The Second Sex - one which is inseparable from her

\footnotetext{
${ }^{19}$ For instance, I see experimentation as a way of approaching and taking up the location of responsible ally (by which I mean active bystander) in solidarity and political work.
} 
examination of the concrete ambiguities of being a woman-is a Hegelian one. When one speaks or thinks of "being," when one uses conjugations of "to be," there is an inherent ambiguity present in that language between "facts" and possibilities, between what is currently most assuredly the case, and what can be. Speaking of how things "are" in a world structured by social inequalities, in the Introduction to The Second Sex, Beauvoir writes:

The familiar line from George Bernard Shaw sums it up: "The white American relegates the black to the rank of shoe-shine boy, and then concludes that blacks are only good for shining shoes." The same vicious circle can be found in all analogous circumstances: when an individual or a group of individuals is kept in a situation of inferiority, the fact is that he or they are inferior. But the scope of the verb to be must be understood; bad faith means giving it a substantive value, when in fact it has the sense of the Hegelian dynamic: to be is to have become, to have been made as one manifests oneself [as one is manifest] (Beauvoir, Second Sex 12).

Who one is, how free one is, what one means as an object for-others, is inescapably tied to a becoming structured by being in a world with others. Beauvoir reads the significance of Hegel's "to be" to say that what one's actions, self, and words mean, the significance of one's experiential and intellectual relation with the world, is neither up to oneself alone, nor mere "reflection," reproduction, or expression of what the world "is." The meanings we make are not passing ideas - they often matter to the very material significance of human situations and of the world as it is for others. Our metaphysical lives, or human being insofar as it is metaphysical, is structured in a way that, to be taken up responsibly, requires what I am claiming is an experimental ethos, a form of selfconscious subjectivity, that can be lived experimentally.

To give the world meaning by trying to know it is, in a Beauvoirean sense, to find in or introduce to the world the significance that an object of knowledge has for oneself, but not as one's own discovery, or as though the matter were finished. Rather, it is (might be) to experiment or suggest in the (Beauvoirean) sense I am describing, to employ a kind of metaphysical stance that both assumes the ambiguity of any attempt to foreclose worldly possibilities, and throws into the world ambiguously foreclosed, diffractive "objects" for-others, tied to their subject-actors. Indeed, the existence and success of Beauvoir's novels suggest that a written work can also be a kind of experimental engagement: her philosophical work suggests that the very texts of philosophy stand, to use Donna Haraway's term, as diffractive objects, subjective engagements in the world for others. 
As Beauvoir concedes in much of her work, it is not simply that scientific inventions and interventions contribute to "humanity" through their use-value in practice: inventions of thought, like laboratories and novels, can change how all or parts of "humanity" understands itself, and such contributions can be empowering, debilitating, and both at once. Employing an experimental ethos might, then, be a way of assuming the continuous resignification of ambiguous situation. It might be a way of assuming responsibility for actions that produce a world we do not control. $^{20}$

${ }^{20}$ Completion of this paper was supported by an Insight Development Grant from the Social Sciences and Humanities Research Council of Canada. An earlier version was presented at the 2010 joint meeting of International Association of Women Philosophers and C-SWIP at Western University in London, Ontario, and I would like to thank the audience for their insightful questions and encouragement. My thanks also go to Lorraine Code, Kirby Maguire, Edith Rattary Skeard, Esteve Morera, Robert Piercey, Jan Purnis, and Jim Vernon, who variously provided helpful comments, generous editing, research assistance, and moral and technical support. I would also like to thank at least four anonymous reviewers for reading my work so carefully (and for doing the important work of reviewing), as well as the editorial staff at PhoenEx for their assistance and patience. 


\section{Works Cited}

BARAD, Karen. Meeting the Universe Halfway: Quantum Physics and the Entanglement of Matter and Meaning. Durham, NC: Duke University Press, 2007.

BAUER, Nancy. Simone de Beauvoir, Philosophy, and Feminism. New York: Columbia University Press, 2001.

BEAUVOIR, Simone de. Les mandarins. Paris: Gallimard, 1954.

-. The Ethics of Ambiguity. Trans. Bernard Frechtman. New York: Philosophical Library, 1976.

-. "Analysis of Claude Bernard's Introduction to the Study of Experimental Medicine." Trans. Marybeth Timmerman. Simone de Beauvoir: Philosophical Writings. Ed. Margaret A. Simons. Chicago: University of Illinois Press, 2004, pp. 23-30.

-. "Pyrrhus and Cineas." Trans. Marybeth Timmerman. Simone de Beauvoir: Philosophical Writings, pp. 89-149.

- . "A Review of The Phenomenology of Perception by Maurice MerleauPonty." Trans. Marybeth Timmermann. Simone de Beauvoir: Philosophical Writings, pp. 159-164.

—. "Literature and Metaphysics." Trans. Margaret A. Simons. Simone de Beauvoir: Philosophical Writings, pp. 261-277.

-. The Second Sex. Trans. Constance Borde and Sheila MalovanyChevallier. New York: Vintage Books, 2011.

—. "What Can Literature Do?" Trans. Marybeth Timmerman. Simone de Beauvoir: "The Useless Mouths" and Other Literary Writings. Ed. Margaret A. Simons \& Marybeth Timmerman. Chicago: University of Illinois Press, 2011, pp. 197-209.

BERNARD, Claude. An Introduction to the Study of Experimental Medicine. Trans. Henry Copley Greene, A.M.. New York: Dover Publications, Inc., 1958.

BOYLE, Robert. The Philosophical Works of the Honourable Robert Boyle, Esq., vol. II. Ed. Peter Shaw. London: W. \& J. Innys, 1725. 
-. The Boyle Project. Ed. Michael Hunter. Birkbeck College/The Royal Society. 2004. Web. Accessed March 4, 2014.

FULLBROOK, Edward. "Introduction to Two Unpublished Chapters of She Came to Stay." Simone de Beauvoir: Philosophical Writings. Ed. Margaret A. Simons. Chicago, IL: University of Illinois Press, 2004, pp. 33-40.

FULLBROOK, Edward and Kate Fullbrook. Simone de Beauvoir: A Critical Introduction. Malden, MA: Polity Press, 1998.

HARAWAY, Donna. Simians, Cyborgs, and Women: The Reinvention of Nature. New York: Routledge, 1991.

Modest_Witness@Second_Millennium.Female_Man@_Meets_Onc

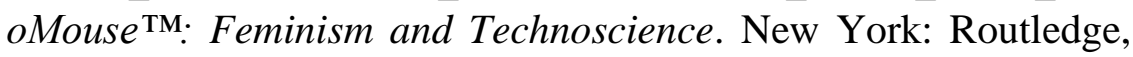
1997.

HEGEL, G.W.F. Philosophy of Nature. Trans. A.V. Miller. Oxford: Oxford University Press, 2004.

HEINÄMAA, Sara. "The Background of Simone de Beauvoir's Metaphysical Novel: Kierkegaard and Husserl," in Acta Philosophica Fennica 79, 2006.

HENGEHOLD, Laura. "Introduction to 'What Can Literature Do?'," in Simone de Beauvoir: "The Useless Mouths" and Other Literary Writings. Ed. Margaret A. Simons \& Marybeth Timmerman. Chicago: University of Illinois Press, 2011, pp. 191-196.

HOLVECK, Eleanore. Simone de Beauvoir's philosophy of lived experience: Literature and Metaphysics. Lanham, MD: Rowman \& Littlefield Publishers, Inc., 2002.

KLASSEN, Abigail. "Beauvoir, the Scandal of Science, and Skepticism as a Method," in Hypatia 28(4): Fall 2013, pp. 835-851.

KRUKS, Sonia. Retrieving Experience: Subjectivity and Recognition in Feminist Politics. Ithaca, N.Y.: Cornell University Press, 2001.

MUDDE, Anna. "'Before you formed in the womb I knew you:' Sex Selection and Spaces of Ambiguity," in Hypatia 25(3): Summer 2010, pp. 553-576. 
MURDOCH, Iris. Existentialists and Mystics: Writings on Philosophy and Literature. Ed. Peter Conradi. New York: Penguin, 1999.

POTTER, Elizabeth. Gender and Boyle's Law of Gases. Bloomington: Indiana University Press, 2001.

SHAPIN, Steven. A Social History of Truth: Civility and Science in Seventeenth-Century England. Chicago: University of Chicago Press, 1994.

SIMONS, Margaret A. and Hélène N. PETERS. Introduction to "Analysis of Claude Bernard's Introduction to the Study of Experimental Medicine", in Simone de Beauvoir: Philosophical Writings. Ed. Margaret A. Simons. Chicago: University of Illinois Press, 2004, pp. 15-22.

SIRRIDGE, Mary. "Philosophy in Beauvoir's Fiction," in The Cambridge Companion to Simone de Beauvoir. Ed. Claudia Card. Cambridge: Cambridge University Press, 2003, pp. 129-148.

VINTGES, Karen. Philosophy as Passion: The Thinking of Simone de Beauvoir. Trans. Anne Lavelle. Indianapolis, IN: Indiana University Press, 1996.

WARNOCK, Mary. Existentialism. Oxford: Oxford University Press, 1970. 